\title{
Research Article \\ Antiasthma Activities of Moringa oleifera Lam. Leaves Extract on the Eosinophil Count and Mast Cells in BALB/c Mice
}

\author{
Dian Arsanti Palupi ${ }^{*}$ \\ Tri Wahyuni Prasetyowati ${ }^{1}$ \\ Dwi Murtiningsih ${ }^{1}$ \\ Dede Mahdiyah 2 \\ ${ }^{1}$ Department of Pharmacy, STIKES \\ Cendekia Utama Kudus, Kudus, Central \\ Java, Indonesia \\ 2Department of Pharmacy, Universitas \\ Sari Mulia, Banjarmasin, South \\ Kalimantan, Indonesia \\ *email: arsanti_palupi@yahoo.com \\ Keywords: \\ Asthma \\ Eosinophil \\ Moringa oleifera
}

\begin{abstract}
Asthma is a chronic inflammation of the respiratory tract. This study aimed to prove Moringa oleifera Lam. leaves extract's effect on reducing the eosinophil count and mast cells in asthmatic mice. Twenty BALB/c mice that met the inclusion criteria were divided into four groups of standard control (K1), negative control (K2), dexamethasone (K3), and M. oleifera leaves extract (K4). On days 0 and 7 , intraperitoneal ovalbumin (OVA) was sensitized. On days 14, 16, and 18, mice were re-sensitized by inhalation using $1 \%$ OVA in sterile $0.9 \% \mathrm{NaCl}$. On days 18 to 25, K1 and $\mathrm{K} 2$ groups were given $\mathrm{Na}-\mathrm{CMC}$, the $\mathrm{K} 3$ group was given dexamethasone $1.3 \mu \mathrm{g} /$ day, and the $\mathrm{K} 4$ group was given $M$. oleifera leaves extract $3.9 \mathrm{mg} /$ day. On the $25^{\text {th }}$ day, the mice were terminated to analyze the eosinophil count and stable bronchiolar mast cells. In conclusion, M. oleifera leaves extract was proven to decrease the eosinophil count with a p-value $<0.05$ and could stabilize bronchiolar mast cells with a p-value $<0.05$.
\end{abstract}

Received: December 11th 2020

Accepted: May 22nd, 2021

Published: August 30th, 2021

(C) 2021 Dian Arsanti Palupi, Tri Wahyuni Prasetyowati, Dwi Murtiningsih, Dede Mahdiyah. Published by Institute for Research and Community Services Universitas Muhammadiyah Palangkaraya. This is an Open Access article under the CC-BY-SA License (http://creativecommons.org/licenses/by-sa/4.0/). DOI: https://doi.org/10.33084/bjop.v4i3.1916

\section{INTRODUCTION}

Asthma is a disease with an increasing prevalence rate, and there is a strong interaction between airway epithelial cells and the immune system against the pathogenesis of asthma ${ }^{1}$. The most common immunopathology in asthma is inflammation of type 2 characterized by processes in the airway epithelium involving cytokines ${ }^{2}$. Symptoms of asthma include wheezing, shortness of breath, heavy chest, and coughing at night and early morning. There is muscle contraction in the bronchial walls, swelling of the bronchial mucosa, and increased mucus production in the secretory cells of the bronchial mucosa, resulting in increased resistance to airflow through the narrowed bronchi. This condition occurs in shortness of breath ${ }^{3,4}$. The increase in the eosinophil count in asthmatic patients correlated with the severity of the respiratory failure and was predicted to increase the risk of sequential subexacerbations. Immunoglobulin $\mathrm{E}$ ( $\operatorname{IgE}$ ) is involved early in the inflammatory cascade and may be considered a cause of allergic asthma ${ }^{5,6}$.

Moringa oleifera Lam. is considered a miracle plant with many benefits for humans and is credible for providing good nutrition and healing and preventing many diseases ${ }^{7}$. The pharmacologically reported effects include antibacterial, antifungal, antiviral, anti-inflammatory and analgesic, antioxidant, hypotensive, antiulcer, cardioprotective anesthetic, antiurolithic, and wound healing activity ${ }^{8-12}$. The M. oleifera plant has various therapeutic properties. For example, the general nutritional content of $M$. oleifera to several specific properties, including anti-inflammatory, antimicrobial, 
antihyperglycemic, antioxidant and anticancer properties $^{13}$. The secondary metabolites of $M$. oleifera leaves are alkaloids, saponins, phenolics, tannins, flavonoids, and steroids ${ }^{14}$. Oral administration of $M$. oleifera aqueous extract has been shown to reduce symptoms of type I allergy in ovalbumin-induced rats. Aqueous extract of $M$. oleifera altered the $\mathrm{T}$ helper (Th)1/Th2 balance towards Th1 dominance in the allergy model in mice, resulting in suppression of mast cell activation, followed by histamine release ${ }^{15}$.

Treatment decisions must consider the biological background in this case of inflammation as they tend to predict the patient's response to asthma treatment ${ }^{16}$. Agrawal and Mehta ${ }^{17}$ studied fine powder dry seeds of 3 $\mathrm{g}$ on $M$. oleifera seeds for three weeks showing a significant increase in forced vital capacity, forced expiratory volume in one second, and peak expiratory flow rate values in patient subjects. Moringa oleifera leaves extract was proven to decrease the eosinophil count and could stabilize bronchiolar mast cells ${ }^{18}$. However, research on the anti-plasma activity of $M$. oleifera leaves extract reduces the eosinophil count, and the stability of the number of mast cells in asthmatic mice has not been reported. Therefore, this study aims to prove the effect of M. oleifera leaves extract on reducing eosinophils and mast cells in asthmatic mice.

\section{MATERIALS AND METHODS}

\section{Materials}

The materials used in this study were M. oleifera Lam. leaves extract (Deltomed Laboratories, Indonesia), dexamethasone (Cayman Chemical, US), ovalbumin (OVA) (Worthington Biochemical Corporation, US), and alhydrogel $\AA$ (InvivoGen, US). The main instruments used in this study were electronic nebulizer, automated hematology analyzer XS1000i/800i (Sysmex, Japan), and Olympus digital microscope OptiLab Pro 6.1. The software used for data analysis was IBM SPSS Statistics ®16.0.

\section{Methods}

Preparation of test animals

The test animals used were female BALB/c mice weighing 20-30 g, which has been acclimatized for a week. All test animals were given drink and standard feed ad libitum. Female BALB/c mice were used because they showed a better response to OVA than males ${ }^{19}$.

\section{Research design}

This study used a laboratory experimental quantitative approach with a post-test only control group design in asthmatic mice in vivo. The test group was divided into four groups: standard control (K1), negative control (K2), positive control (K3), and M. oleifera leaves extract group (K4). The treatment dose for $M$. oleifera leaves extract produced by Deltomed Laboratories was 1500 mg/day, with the conversion dose for mice was $1500 \mathrm{mg} \times 0.0026$ $=3.9 \mathrm{mg} /$ day. For the standard control group, BALB/c mice were given sterile $0.9 \% \mathrm{NaCl}$ by intraperitoneal injection on days 0 and 7. On days 14, 16, and 18, inhalation was carried out with sterile $0.9 \% \mathrm{NaCl}$ as much as $8 \mathrm{~mL}$ per treatment by inhalation using an electronic nebulizer for 20 minutes with airflow volume and volume nebulization on a scale of 1 on day 1 . On days $18,19,20,21,22,23$, and 24, mice were treated with $0.5 \% \mathrm{Na}-\mathrm{CMC}$ orally $1 \mathrm{~mL} /$ day. For K2, K3, and K4 groups, all BALB/c mice have sensitized with $10 \mu \mathrm{g}$ OVA $+1 \mathrm{mg}$ alhydrogel $\AA$ suspended in $0.5 \mathrm{~mL}$ of $0.9 \%$ sterile $\mathrm{NaCl}$ by intraperitoneal injection on days 0 and 7 . On days 14, 16, and 18, inhalation was carried out with sterile $0.9 \% \mathrm{NaCl}$ as much as $8 \mathrm{~mL}$ per treatment by inhalation using an electronic nebulizer for 20 minutes with airflow volume and volume nebulization on a scale of 1 on day 1 . On days $18,19,20,21,22,23$, and 24 , mice were treated with $0.5 \% \mathrm{Na}-\mathrm{CMC}$ orally $1 \mathrm{~mL} /$ day $(\mathrm{K} 2)$, $1.3 \mu \mathrm{g}$ dexamethasone orally $1 \mathrm{~mL} /$ day (K3), and $3.9 \mathrm{mg}$ 
M. oleifera leaves extract orally $1 \mathrm{~mL} /$ day (K4). The research design schematic was shown in Figure 1.

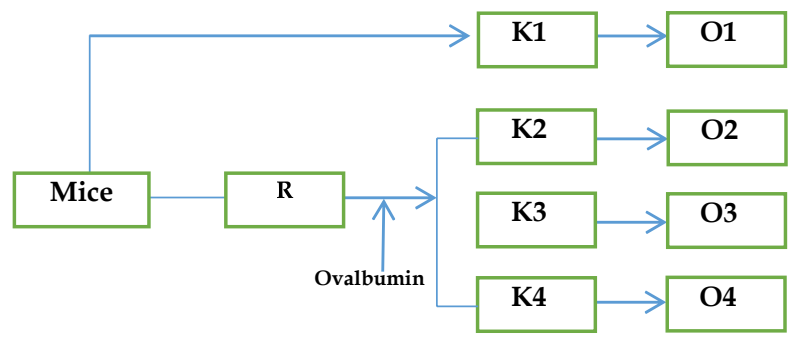

Figure 1. Research design. R: Randomization; O1-O4: Observation of the eosinophil count and bronchial mast cells

\section{Examination of eosinophil count}

Blood sampling was performed to the anesthetized mice by an intraperitoneal injection of ketamine $200 \mu \mathrm{g} / \mathrm{g}$. The blood collection location was in the retro-orbital sinus/eye of mice using a hematocrit capillary pipette. The application could be made by inserting the pipette at an angle of $45^{\circ}$. This method could produce large volumes of blood, and samples could be obtained in both eyes alternately, accommodated in the EDTA blood tube ${ }^{20}$. The examination of the blood eosinophils count was the eosinophils cell count $\times 10^{9} / \mathrm{L}$ of blood plasma, calculated by an automated hematology analyzer. This variable size scale was a ratio. Data analysis was performed using one-way ANOVA and analyzed by post hoc test to determine the difference between the two treatment groups. Data were presented as average \pm SD . Significance was defined at the $\mathrm{p}<0.05$ level.

\section{Examination of bronchiolar mast cells}

Mast cell examination was carried out by histopathology of the mice's lungs with Toluidine blue staining and observed with a 400x magnification software microscope Image OptiLab Pro 6.121. This variable size scale was a ratio. Data analysis was performed using one-way ANOVA and then analyzed by post hoc test to determine the difference between the two treatment groups. Data were presented as average \pm SD. Significance was defined at the $p<0.05$ level.

\section{Ethical considerations}

This research was conducted after obtaining approval from the health research biotech commission of the Faculty of Medicine, Universitas Islam Sultan Agung Semarang with Ethical Clearance No. 110/IV/2020/Bioethical Commission.

\section{RESULTS AND DISCUSSION}

Normality and homogeneity analysis of the eosinophil count and mast cells

The data normality test for the eosinophil count was performed with Shapiro-Wilk, with a p-value $>0.05$, indicating that the data were normally distributed as presented in Table I. As for the homogeneity of the data, the post hoc test results were obtained with a p-value $>0.05$, indicating that the data obtained for the eosinophil count and mast cells were homogeneous, as shown in

\section{Table II.}

Table I. Normality of data with Shapiro-Wilk test

\begin{tabular}{ccc}
\hline \multirow{2}{*}{ Groups } & \multicolumn{2}{c}{ Variable } \\
\cline { 2 - 3 } & Eosinophil count (cell count $\mathbf{1 0} / \mathbf{L}$ ) & Mast cells \\
\hline K1 & 0.777 & 0.119 \\
K2 & 0.429 & 0.325 \\
K3 & 0.697 & 0.119 \\
K4 & 0.427 & 0.314 \\
\hline
\end{tabular}

Table II. Data homogeneity by post hoc test

\begin{tabular}{ccc}
\hline \multirow{2}{*}{ Parameter } & \multicolumn{2}{c}{ Variable } \\
\cline { 2 - 3 } & Eosinophil count & Mast cells \\
\hline p-value & 0.117 & 0.509 \\
\hline
\end{tabular}

\section{Examination of eosinophil count}

The statistical analysis of the test results for the average, $\mathrm{SD}, \mathrm{F}$ value, and $\mathrm{p}$-value of the eosinophil count in all groups were presented in Table III. The K2 had the highest average value of all other groups. This finding indicates that the high average value of eosinophils in the K2 could be reduced by administering dexamethasone or $M$. oleifera leaves extract. The average difference between the two groups analyzed by post hoc test showed that the average eosinophil count between the K2 was $2+0.71 x$ 
$10^{9} / \mathrm{L}$, and the $\mathrm{K} 3$ was $0.4 \pm 0.11 \times 10^{9} / \mathrm{L}$, with a p-value of 0.002 indicate that there was a significant difference between $\mathrm{K} 2$ and $\mathrm{K} 3$. The average difference in the $\mathrm{K} 3$ was $0.4 \pm 0.11 \times 10^{9} / \mathrm{L}$, and the $\mathrm{K} 4$ was $0.48 \pm 0.15 \times 10^{9} / \mathrm{L}$, with a p-value of 0.503 , suggesting no statistically significant difference between the $\mathrm{K} 3$ and $\mathrm{K} 4$ groups in reducing the eosinophil count. The analysis results of the average difference above resulted in an F value of 6.773 and a pvalue of 0.001, suggesting that the eosinophil count was significantly different between each study group.

Eosinophils are promoters of type-2 inflammatory environment, which contribute to airway renovation in asthma, wherein eosinophils can increase airway hyperresponsiveness (AHR) and mucus hypersecretion ${ }^{22,23}$. Moringa oleifera seed oil is proven to contain flavonoid compounds that have biological activity as anti-asthma by reducing the thickness of the bronchial epithelium of asthmatic mice ${ }^{24}$. The subchronic toxicity effect of $M$. oleifera leaves extract based on liver histopathology shows mild reversible damage, and kidney histopathology shows that the renal filtration function of all treatment groups is still expected ${ }^{25}$. Moringa oleifera leaves contain phenolic compounds that contribute to higher antioxidant activity. They can be used as a potential source of natural antioxidants in pharmaceuticals to improve the function of the endogenous antioxidant system and help reduce free radical levels in the body ${ }^{26}$. Eosinophils contribute to asthma severity and may persist despite guideline-based treatment ${ }^{27}$. The characteristic picture of inflammation is characterized by an increase in the number of activated eosinophils causing damage to the airway epithelium ${ }^{28}$.

Table III. Average, SD, F value, and p-value of eosinophils count

\begin{tabular}{lcccc}
\hline \multicolumn{1}{c}{$\begin{array}{c}\text { Eosinophil count } \\
\text { (cells } \mathbf{~ 1 0 9 )}\end{array}$} & K1 & K2 & K3 & K4 \\
\cline { 2 - 5 } & 0.38 & 0.9 & 0.4 & 0.48 \\
Average & 0.14 & 0.3 & 0.11 & 0.15 \\
SD & \multicolumn{5}{c}{6.773} \\
Fvalue & \multicolumn{5}{c}{0.001} \\
p-value & \multicolumn{5}{c}{} \\
\hline
\end{tabular}

\section{Examination of bronchiolar mast cells}

The test results for the average, SD, F value, and p-value of the mast cells in groups $K 1, K 2, K 3$, and $K 4$ were presented in Table IV. The analysis of the average difference above resulted in an F value of 10.062 and a pvalue of 0.001 , which means that the number of mast cells was significantly different between each study group. The K3 had the highest average number of stable mast cells than the $\mathrm{K} 2$ and $\mathrm{K} 4$.

The average difference between the two groups analyzed by post hoc test showed that the average number of mast cells that were stable between the $\mathrm{K} 2$ was $2 \pm 0.71$ and the $\mathrm{K} 3$ was $4 \pm 1$, with a p-value of 0.003 , indicates that there was a significant difference between the $\mathrm{K} 2$ and $\mathrm{K} 3$ groups. It could be assumed that dexamethasone could stabilize mast cells. The average difference between the $\mathrm{K} 3$ was $4 \pm 1$, while the $\mathrm{K} 4$ was $3.2 \pm 0.84$, with a p-value of 0.176 , which means that statistically, there was no significant difference between the $\mathrm{K} 3$ and $\mathrm{K} 4$ groups in stabilizing mast cells.

Table IV. Average, SD, F value, and p-value of mast cells

\begin{tabular}{lcccc}
\hline \multirow{2}{*}{ Mast cells } & \multicolumn{4}{c}{ Group } \\
\cline { 2 - 5 } & K1 & K2 & K3 & K4 \\
\hline Average & 5 & 2 & 4 & 3.2 \\
SD & 1 & 0.71 & 1 & 0.84 \\
Fvalue & \multicolumn{5}{c}{10.062} \\
p-value & \multicolumn{5}{c}{0.001} \\
\hline
\end{tabular}

The analysis of the number of stable bronchial mast cells in all groups was carried out by taking pulmonary organs. The histopathological test was carried out with Toluidine Blue staining, observed microscopically with a magnification of 400x. The histopathological picture of stabilizer mast cells was presented in Figure 2. In the lungs of patients with allergic asthma, mast cells accumulate in smooth muscle, bronchial epithelium, and alveolar parenchyma. This unique location of pulmonary mast cells can be replicated using a mouse model of allergic asthma ${ }^{29}$. Mast cells migrate to inflamed tissue and release pro-inflammatory mediators by 
degranulation upon activation of cell surface receptors such as high-affinity IgE receptor (FceRI), prostaglandin E2 receptor (PGE2), or receptors for stem cell factor in human and mouse mast cells ${ }^{30}$.
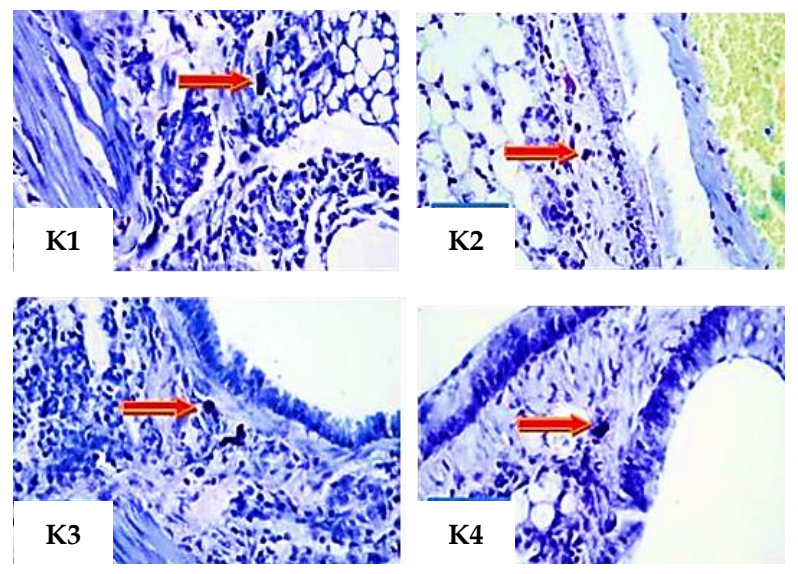

Figure 2. Comparison of stable mast cells in the standard control group (K1), negative control group (K2), positive control group (K3), and Moringa oleifera leaves extract group (K4), with toluidine blue staining and 400x magnification. Red arrows indicate stable mast cells

This study shows that $M$. oleifera leaves could reduce the eosinophil count and stabilize mast cells; in line with the research of Suresh et al. ${ }^{31}$, which reported that the methanol extract of $M$. oleifera leaves given to guinea pigs shows anti-plasma activity such as blocking the release of inflammatory mediators to local lung tissue and bronchospasm, mast cell degranulation, immune reactions, and anaphylactic reactions. This was found to inhibit the inflammatory mediator, histamine. Moringa oleifera extractcan inhibit the release of $\beta$-hexosaminidase, histamine, and tumor necrosis factor (TNF)- $\alpha$ more actively than ketotifen fumarate. Moringa oleifera leaves has mast cell stabilizing activity and its potential to inhibit the final phase of the allergic response ${ }^{32}$.

\section{CONCLUSION}

Moringa oleifera Lam. leaves extract has been shown to reduce the eosinophil count and can stabilize the number of mast cells in asthmatic mice. There was no statistically significant difference between $M$. oleifera leaves extract.
Compared with positive controls given dexamethasone in reducing the eosinophil count, the p-value was 0.503 , and there was no statistically significant difference between $M$. oleifera leaves extract. While compared with positive controls (dexamethasone) to stabilize mast cells, the p-value was 0.176 .

\section{ACKNOWLEDGMENT}

The authors would like to thank the laboratory technicians and staff of the department of pharmacology, Universitas Islam Sultan Agung, Semarang. We also thank STIKES Cendekia Utama Kudus for the permission for the research. All authors contribute to financing this work.

\section{AUTHORS' CONTRIBUTION}

Dian Arsanti Palupi: conceptualization, supervision, methodology, data curation, data analysis, validation, writing-original draft \& editing. Tri Wahyuni Prasetyowati: conceptualization, supervision, data analysis, writing-review \& editing. Dwi Murtiningsih: conceptualization, methodology, data curation, data analysis, writing-review \& editing. Dede Mahdiyah: project administration, data curation, data analysis, writing-review \& editing.

\section{DATA AVAILABILITY}

None.

\section{CONFLICT OF INTEREST}

The authors declare no conflict of interest.

\section{REFERENCES}

1. Quirt J, Hildebrand KJ, Mazza J, Noya F, Kim H. Asthma. Allergy Asthma Clin Immunol. 2018;14(Suppl 2):50. doi:10.1186/s13223-018-0279-0 
2. Fahy JV. Type 2 inflammation in asthma--present in most, absent in many. Nat Rev Immunol. 2015;15(1):57-65. doi:10.1038/nri3786

3. Kalolella AB. Sleeping position and reported nighttime asthma symptoms and medication. Pan Afr Med J. 2016;24:59. doi:10.11604/pamj.2016.24.59.9159

4. Kaufman G. Asthma: pathophysiology, diagnosis and management. Nurs Stand. 2011;26(5):48-56. doi:10.7748/ns2011.10.26.5.48.c8744

5. Jackson DJ,Humbert M, Hirsch I, Newbold P, Gil EG. Ability of Serum IgE Concentration to Predict Exacerbation Risk and Benralizumab Efficacy for Patients with Severe Eosinophilic Asthma. Adv Ther. 2020;37(2):718-29. doi:10.1007/s12325-019-01191-2

6. Nakagome K, Nagata M. Involvement and Possible Role of Eosinophils in Asthma Exacerbation. Front Immunol. 2018;9:2220. doi:10.3389/fimmu.2018.02220

7. Tshabalala T, Ncube B, Madala NE, Nyakudya TT, Moyo HP, Sibanda M, et al. Scribbling the Cat: A Case of the "Miracle" Plant, Moringa oleifera. Plants. 2019;8(11):510. doi:10.3390/plants8110510

8. Xu YB, Chen GL, Guo MQ. Antioxidant and AntiInflammatory Activities of the Crude Extracts of Moringa oleifera from Kenya and Their Correlations with Flavonoids. Antioxidants. 2019;8(8):296. doi:10.3390/antiox8080296

9. Vergara-Jimenez M, Almatrafi MM, Fernandez ML. Bioactive Components in Moringa Oleifera Leaves Protect against Chronic Disease. Antioxidants. 2017;6(4):91. doi:10.3390/antiox6040091

10. Martínez-González CL, Martínez L, Martínez-Ortiz EJ, González-Trujano ME, Déciga-Campos M, Ventura-Martínez R, et al. Moringa oleifera, a species with potential analgesic and anti-inflammatory activities. Biomed Pharmacother. 2017;87:482-8. doi:10.1016/j.biopha.2016.12.107

11. Adelapo AA, Falayi OO, Oyagbemi AA. Evaluation of the analgesic, anti-inflammatory, anti-oxidant, phytochemical and toxicological properties of the methanolic leaf extract of commercially processed Moringa oleifera in some laboratory animals. J Basic Clin Physiol Pharmacol. 2015;26(5):491-9. doi:10.1515/jbcpp-2014-0105
12. Razis AFA, Ibrahim MD, Kntayya SB. Health benefits of Moringa oleifera. Asian Pac J Cancer Prev. 2014;15(20):8571-6. doi:10.7314/apjcp.2014.15.20.8571

13. Meireles D, Gomes J, Lopes L, Hinzmann M, Machado J. A review of properties, nutritional and pharmaceutical applications of Moringa oleifera: integrative approach on conventional and traditional Asian medicine. Adv Tradit Med. 2020;20:495-515. doi:10.1007/s13596-020-00468-0

14. Bhattacharya A, Tiwari P, Sahu PK, Kumar S. A Review of the Phytochemical and Pharmacological Characteristics of Moringa oleifera. J Pharm Bioallied Sci. 2018;10(4):181-91. doi:10.4103/JPBS.JPBS_126_18

15. Hagiwara A, Hidaka M, Takeda S, Yoshida H, Kai H, Sugita C, et al. Anti-Allergic Action of Aqueous Extract of Moringa oleifera Lam. Leaves in Mice. Eur Med Plants. 2016;16(3):1-10. doi:10.9734/EJMP/2016/28566

16. Bush A. Pathophysiological Mechanisms of Asthma. Front Pediatr. 2019;7:68. doi:10.3389/fped.2019.00068

17. Agrawal B, Mehta A. Antiasthmatic activity of Moringa oleifera Lam: A clinical study. Indian J Pharmacol. 2008;40(1):28-31. doi:10.4103/02537613.40486

18. Goyal BR, Goyal RK, Mehta AA. Investigation into the mechanism of anti-asthmatic action of Moringa oleifera. J Diet Suppl. 2009;6(4):313-27. doi:10.3109/19390210903280199

19. Melgert BN, Postma DS, Kuipers I, Geerlings M, Luinge MA, van der Strate BWA, et al. Female mice are more susceptible to the development of allergic airway inflammation than male mice. Clin Exp Allergy. 2005;35(11):1496-503. doi:10.1111/j.13652222.2005.02362.x

20. Yardeni T, Eckhaus M, Morris HD, Huizing M, Hoogstraten-Miller S. Retro-orbital injections in mice. Lab Anim. 2011;40(5):155-60. doi:10.1038/laban0511155

21. Puebla-Osorio N, Sarchio SNE, Ullrich SE, ByrneSN. Detection of Infiltrating Mast Cells Using a Modified Toluidine Blue Staining. Methods Mol Biol. 2017;1627:213-22. doi:10.1007/978-1-4939-7113-8_14

22. Choi $Y$, Lee $Y$, Park HS. Which Factors Associated With Activated Eosinophils Contribute to the Pathogenesis of Aspirin-Exacerbated Respiratory 
Disease? Allergy Asthma Immunol Res. 2019;11(3):320-9. doi:10.4168/aair.2019.11.3.320

23. McBrien CN, Menzies-Gow A. The Biology of Eosinophils and Their Role in Asthma. Front Med. 2017;4:93. doi:10.3389/fmed.2017.00093

24. Palupi DA, Martati E. Efek Pemberian Minyak Biji Kelor (Moringa Oliefera L.) Sebagai Terapi Asma Terhadap Gambaran Hispatologi Epitel Bronkiolus Mencit BALB/c. Cendekia J Pharm. 2019;3(1):37-64. doi:10.31596/cjp.v3i1.42

25. Wulandari MA, Solikhah LI, Wulan SN. Uji Toksisitas Subkronis Serbuk, Ekstrak Air, dan Ekstrak Pekat Suplemen Kalsium Daun Kelor (Moringa oleifera Lam.) pada Fungsi Hepar dan Ginjal Tikus Wistar (Rattus norvegicus). Jurnal Pangan dan Agroindustri. 2017;5(4):71-82.

26. Mwamatope B, Tembo D, Chikowe I, Kampira E, Nyirenda C. Total phenolic contents and antioxidant activity of Senna singueana, Melia azedarach, Moringa oleifera and Lannea discolor herbal plants. Sci Afr. 2020;9:e00481. doi:10.1016/j.sciaf.2020.e00481

27. Castillo JR, Peters SP, Busse WW. Asthma Exacerbations: Pathogenesis, Prevention, and Treatment. J Allergy Clin Immunol Pract. 2017;5(4):918-27. doi:10.1016/j.jaip.2017.05.001

28. Palupi DA, Sutanto H, Sadhana U, Dharmana E, Mahati E, Sasmito E, et al. The Effect of Nigella Sativa Oil on Number Eosinophils, Neutrophils, Serum IgE Levels to Asthma Mice Resistant of Corticosteroid. Int J Pharm Res. 2020;12(1):896-901. doi:10.31838/ijpr/2020.12.01.171

29. Méndez-Enríquez E, Hallgren J. Mast Cells and Their Progenitors in Allergic Asthma. Front Immunol. 2019;10:821. doi:10.3389/fimmu.2019.00821

30. Krystel-Whittemore M, Dileepan KN, Wood JG. Mast Cell: A Multi-Functional Master Cell. Front Immunol. 2016;6:620. doi:10.3389/fimmu.2015.00620

31. Suresh S, Chhipa AS, Gupta M, Lalotra S, Sisodia SS, Baksi R, et al. Phytochemical analysis and pharmacological evaluation of methanolic leaf extract of Moringa oleifera Lam. in ovalbumin induced allergic asthma. S Afr J Bot. 2020;130:484-93. doi:10.1016/j.sajb.2020.01.046

32. Abd Rani NZ, Kumolosasi E, Jasamai M, Jamal JA, Lam KW, Husain K. In vitro anti-allergic activity of Moringa oleifera Lam. extracts and their isolated compounds. BMC Complement Altern Med. 2019;19(1):361. doi:10.1186/s12906-019-2776-1 